The Bangladesh Veterinarian (2008) 25(1) : 40 - 49

\title{
Ulcer diseases in cultured fish in Mymensingh and surrounding districts
}

\author{
M. Muniruzzaman ${ }^{8 *}$ and M. B. R. Chowdhury \\ Department of Aquaculture, Faculty of Fisheries, Bangladesh Agricultural University, \\ Mymensingh-2202, Bangladesh
}

\begin{abstract}
The status of ulcer diseases in cultured fish in 14 upazilas (sub-districts) of Mymensingh and surrounding six districts were investigated during the winter in 2001-2002 and 2002-2003. Fish were visibly affected by ulcer diseases including epizootic ulcerative syndrome (EUS). Prevalence of disease varied in different districts, months and fish species in the two years. The highest prevalence of disease was in Jamalpur district where $90 \%$ fish ponds in Melandah upazila were affected during 2001-2002, whereas $80 \%$ affected ponds were observed in sadar upazila of Mymensingh district during 2002-2003. The highest prevalence was in January and the lowest in October. The prevalence of ulcer diseases in different fish species varied significantly $(p<0.01)$. Among the 10 affected species, six were histopathologically EUS-positive and four EUS-negatives. Cirrhinus cirrhosus and Barbodes gonionotus were highly affected by ulcer diseases including EUS. (Bangl. vet. 2007. Vol. 25, No. 1. 40-49)
\end{abstract}

\section{Introduction}

Bangladesh is blessed with huge water resources suitable for aquaculture. Fish production is increasing, though Amin (2000) reported that production is substantially hampered due to disease. Diseases in the form of ulcer are often confused with epizootic ulcerative syndrome (EUS), which are more prevalent in winter. Sufficient information is not available to overcome the problem (Chowdhury, 1998; Khan, 2001; Majumder et al., 2001; Rahman and Chowdhury, 1996; Rahman et al., 1998; Sarker et al., 1998). Studies were done in Bangladesh on ulcer diseases of fish by a number of workers with special emphasis on EUS. Majumder et al. (2001) suggested that ulcer diseases should be studied in order to take necessary measures against the pathogens. There is anecdotic information on ulcer diseases but very few surveys. The objectives of the present study were to determine the prevalence of ulcer diseases in cultured fish during winter in Mymensingh and its surrounding six districts, as in this part of the country fisheries are important.

\section{Materials and Methods}

Selection of study area

Field survey of ulcer diseases was carried out in cultured fish in Mymensingh and its surrounding six districts, Kishoreganj, Netrokona, Sherpur, Jamalpur, Tangail

\footnotetext{
8 Senior Upazila Fisheries Officer, Jhenaidah Sadar, Jhenaidah, Bangladesh

${ }^{*}$ Correspondence :- E-mail : drmz_65@yahoo.com
} 
and Gazipur. The sampling periods were October 2001 to March 2002 and October 2002 to March 2003, when ulcer diseases in fish commonly occur. Two upazilas were randomly selected from each district. Ten fish culture ponds at different locations within each upazila were selected.

\section{Disease investigation and sampling of fish}

A total of 100 fish belonging to different species were caught by seine or cast net randomly and investigated clinically. Among the investigated fish, 10 were randomly sampled considering their disease signs and were immediately brought to the laboratory in the same pond water in a bucket.

Fish with lesions were diagnosed clinically as described by Post (1987) and Tonguthai et al. (1999). EUS-affected fish were recognized according to the clinical signs suggested by Roberts et al. (1989); Vishwanath et al. (1997). Briefly, the signs were: Type-1: early lesions, pinhead-sized red spots on the body surface with no noticeable haemorrhage or ulceration and skin around the spots normal with no discolouration; Type-2: moderately advanced lesions - approximately $2-4 \mathrm{~cm}$ diameter raised, circular, discoloured areas on the body surface, and soft with relatively intact skin and scales; Type-3: advanced lesions - circular or oval, open dermal ulcers, usually extending into the skeletal muscle, with large haemorrhagic and necrotic open ulcers on the body surface, devoid of epidermis and scales with loss of dermis.

A pond was confirmed as EUS-positive when at least one fish was found with typical EUS-like mycotic granulomas on histopathology. Ulcer diseases without mycotic granulomas were confirmed as EUS-negative.

\section{Statistical analysis}

Analysis of variance was performed using MSTAT program. The mean differences were compared with Duncan's Multiple Range Test (Gomez and Gomez, 1984).

\section{Results and Discussion}

During the winter of 2001-2002 and 2002-2003, fish in the investigated ponds in all seven districts were affected by EUS. Haemorrhagic red to yellowish-grey lesions on the body surface were the most common feature (Fig. 1). In severe cases skeletal muscle or viscera were exposed. Fluffy, cotton-like, white to grey or grey to greybrown growth on the skin, fins, gills or eyes of fish indicated fungal infection. Clinical signs of bacterial disease depended on causative agents. In aeromonad septicaemia ulcers were seen on the body surface, tail and fin with erythema at the base of fins. Clinical signs of pseudomonad septicaemia included tail and fin rot, opaque eye, scale loss, and haemorrhagic lesions in the skin and at the base of the fins. Clinical signs of Edwardsiella septicaemia were red colour on the body surface and abdomen, fins and jaws: sometimes, loss of normal pigmentation, protruding 
haemorrhagic anus and opaque eyes were observed. The results obtained in the present study correlate with the findings of Post (1987) and other authors ( Roberts et al., 1989; Tonguthai et al. 1999; Vishwanath et al., 1997).

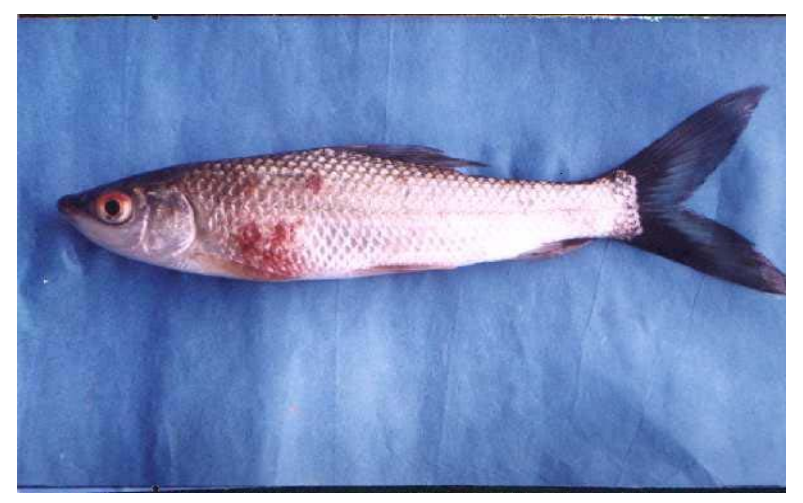

Fig. 1. Red lesion on the body surface of Cirrhina cirrhosus

Out of 140 ponds investigated, mean $( \pm S D)$ prevalence of ulcer diseases was 46.4 \pm 26.2 in 2001-2002 and 54.3 \pm 23.1 in 2002-2003 (Table 1). The prevalence of diseases in affected ponds varied in the two consecutive years.

Table 1. Prevalence of ulcer disease in fish ponds in Mymensingh and surrounding districts

\begin{tabular}{|c|c|c|c|c|c|c|c|}
\hline \multirow[t]{2}{*}{ District } & \multirow[t]{2}{*}{ Upazila } & \multicolumn{3}{|c|}{ Year 2001-2002 } & \multicolumn{3}{|c|}{ Year 2002-2003 } \\
\hline & & $\begin{array}{l}\text { Investigated } \\
\text { ponds }\end{array}$ & $\begin{array}{c}\text { Affected } \\
\text { ponds }\end{array}$ & \begin{tabular}{|c|} 
Prevalence of \\
affected \\
ponds $(\%)$
\end{tabular} & $\begin{array}{l}\text { Investigated } \\
\text { ponds }\end{array}$ & $\begin{array}{c}\text { Affected } \\
\text { ponds }\end{array}$ & $\begin{array}{c}\text { Prevalence of } \\
\text { affected } \\
\text { ponds (\%) }\end{array}$ \\
\hline \multirow[t]{2}{*}{ Mymensingh } & Sadar & 10 & 7 & 70 & 10 & 8 & 80 \\
\hline & Trishal & 10 & 6 & 60 & 10 & 7 & 70 \\
\hline \multirow[t]{2}{*}{ Kishoreganj } & Tarail & 10 & 5 & 50 & 10 & 6 & 60 \\
\hline & Itna & 10 & 4 & 40 & 10 & 5 & 50 \\
\hline \multirow[t]{2}{*}{ Netrakona } & Atpara & 10 & 0 & 0 & 10 & 2 & 20 \\
\hline & Mohanganj & 10 & 2 & 20 & 10 & 4 & 40 \\
\hline \multirow[t]{2}{*}{ Sherpur } & Sadar & 10 & 2 & 20 & 10 & 3 & 30 \\
\hline & Nokla & 10 & 3 & 30 & 10 & 3 & 30 \\
\hline \multirow[t]{2}{*}{ Jamalpur } & Melandah & 10 & 9 & 90 & 10 & 9 & 90 \\
\hline & Motherganj & 10 & 8 & 80 & 10 & 8 & 80 \\
\hline \multirow[t]{2}{*}{ Tangail } & Ghatail & 10 & 7 & 70 & 10 & 8 & 80 \\
\hline & Bhuapur & 10 & 6 & 60 & 10 & 6 & 60 \\
\hline \multirow[t]{2}{*}{ Gazipur } & Shripur & 10 & 3 & 30 & 10 & 4 & 40 \\
\hline & Kapasia & 10 & 3 & 30 & 10 & 3 & 30 \\
\hline $\begin{array}{l}\text { Total } 7 \\
\text { districts }\end{array}$ & $\begin{array}{l}\text { Total } 14 \\
\text { upazilas }\end{array}$ & 140 & 65 & $\begin{array}{c}46.4 \pm 26.2 \\
(\text { Mean } \pm \text { SD) }\end{array}$ & 140 & 76 & $\begin{array}{c}54.3 \pm 23.1 \\
(\text { Mean } \pm \text { SD) }\end{array}$ \\
\hline
\end{tabular}

In both years, the highest prevalence of all ulcer diseases in affected ponds was in Jamalpur district, where $90 \%$ was observed in Melandah and $80 \%$ in Motherganj upazila. During the year 2001-2002, the second highest prevalence was in Mymensingh 
(Sadar 70\% and Trishal 60\%) and Tangail (Ghatail 70\% and Bhuapur 60\%). During the year 2002-2003 80\% of ponds were affected in Mymensingh (Sadar) and in Tangail (Ghatail). During 2001-2002 no pond was affected in Atpara upazila of Netrakona district, but $20 \%$ were affected during 2002-2003. Low prevalence was seen in Sherpur district (20-30\%).
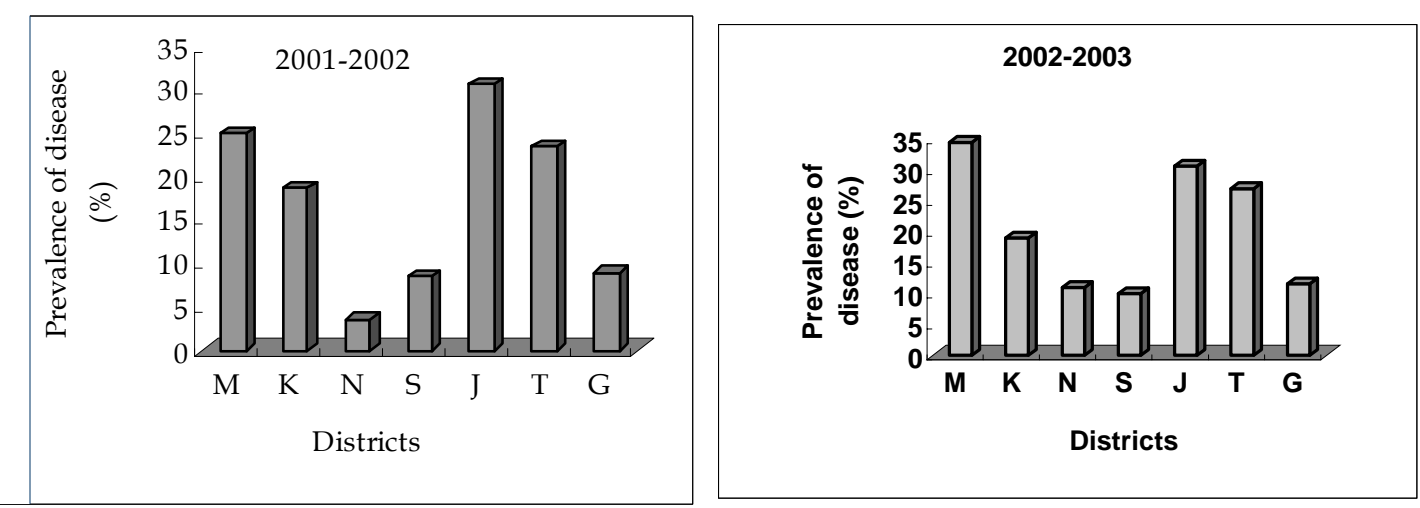

Fig. 2(A, B). Prevalence of ulcer disease cultured fish in Mymensingh and surrounding districts during 2001-2002 and 2002-2003

$M=$ Mymensingh $K=$ Kishoregonj $\quad N=$ Netrakona $\quad S=$ Sherpur

$\mathrm{J}=$ Jamalpur $\quad \mathrm{T}=$ Tangail $\quad \mathrm{G}=$ Gazipur

Values with a, ab, b, c, d, e having dissimilar letter (s) differed significantly $(\mathrm{p}<0.01)$

Barua et al. (1992) reported EUS from 11 districts in Bangladesh where Bogra district of Rajshahi division and Netrokona district of Dhaka division had the highest prevalence of EUS. The disease has been recurring every year throughout Bangladesh in freshwater fish, presumably due to transmission of aetiological agents.

Prevalence of infection varied significantly $(\mathrm{p}<0.01)$ between districts and months (Fig. 2 and Fig. 3). During 2001-2002 prevalence of ulcer diseases in the investigated upazilas ranged from 0 to $67 \%$. The highest mean prevalence of infection was in Jamalpur $(30.8 \%)$, significantly $(p<0.01)$ higher than in other districts. The second highest mean prevalence was in Mymensingh $(25.0 \%)$, but it was not significantly $(p<0.01)$ different from that of Tangail district where $23.5 \%$ fish were infected. The lowest mean prevalence of infection was in Netrakona where 3.5\% fish were infected. Prevalence of infection in Sherpur and Gazipur district differed (8.5$9.0 \%$ ) insignificantly.

Comparing months, the highest prevalence of infection was in January (34.3\%) and the lowest in October (2.1\%). Prevalence of disease increased gradually from November and decreased from February $(21.4 \%)$.

In 2002-2003 the highest prevalence was in Mymensingh (34.5\%) and the lowest in Sherpur $(10.0 \%)$ and Netrakona $(11.0 \%)$. The second highest prevalence was in Jamalpur (30.7\%) followed by Tangail $(27.0 \%)$, Kishoreganj $(19.0 \%)$ and Gazipur $(11.6 \%)$. The prevalence of ulcer diseases in the upazilas ranged from 0 to $68 \%$. As in 
the previous year, the mean prevalence of infection was highest in January $(40.3 \%)$ and lowest in October $(2.0 \%)$. No significant difference in infection was found between December and February or November and March in both the study years. Disease was significantly $(\mathrm{p}<0.01)$ more prevalent in January and February than in other months. The result is in agreement with the findings of Roberts et al. (1993) and Khan (2001) who reported that the prevalence of EUS was high during the winter. The syndrome appears to be seasonal (Tonguthai, 1985) and may be associated with environmental factors especially low temperature (Macintosh and Phillips, 1986). Water level of the investigated ponds gradually decreased during the experimental period but the biomass increased causing overcrowding, which might be another predisposing factor for the diseases.
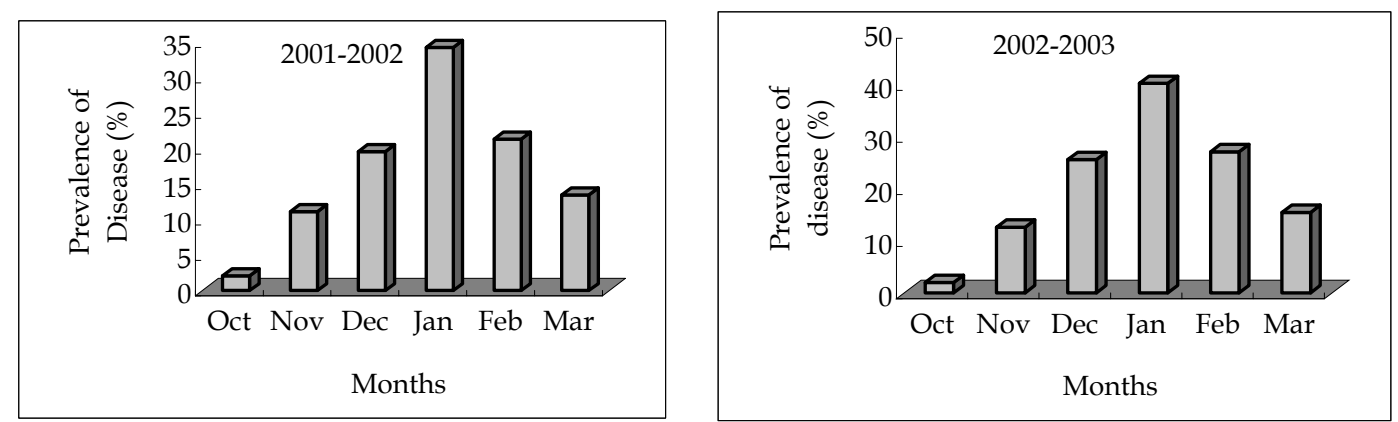

Fig. 3(A, B). Prevalence of ulcer disease outbreak in different months during 2001-2002 and 2002-2003

Values with a, b, c, d having dissimilar letter (s) differed significantly $(\mathrm{p}<0.01)$

Numbers of fish species affected by ulcer diseases varied significantly $(\mathrm{p}<0.01)$ between species and months (Table 2 and Table 3). The investigated cultured fish species were Barbodes gonionotus, Catla catla, Cyprinus carpio var. communis, Cyprinus carpio var. specularis, Cirrhinus cirrhosus, Ctenopharyngodon idellus, Hypophthalmichthys molitrix, Labeo gonius, Labeo rohita, Morulius calbasu and Pangasius hypophthalmus. Among these 11 species, 10 were affected by ulcer diseases in $2001-2002$, and nine in 2002 - 2003. C. cirrhosus and B. gonionotus were badly affected: the mean number of affected fish was 798.3 and 732.3, respectively, during 2001-2002 and 915.3 and 851.3, respectively during 2002-2003. Statistically no significant difference $(p>0.01)$ was observed between mean numbers of affected fish of these two species. The second highest affected species were L. rohita (327.8) and C. catla (271.8) during 2001-2002 and P. hypophthalmus (388.3), L. rohita (372.5) and C. catla (307.7) during 2002-2003. The least affected species during 2001-2002 were C. carpio var. communis (0.3), C. idellus (0.5), M. calbasu (4.8), L. gonius (13.7) and H. molitrix (14.5), whereas during 2002-2003 the least affected species were C. idellus (0.8), M. calbasu (9.5), H. molitrix (12.5) and L. gonius (17.0). No infection was found in C. carpio var. specularis. In the present study, C. cirrhosus and B. gonionotus were severely affected. The less affected species were C. carpio var. communis, C. idellus, M. calbasu, H. molitrix and L. gonius. Ahmed and Rab (1995) reported that B. gonionotus culture ponds were the worst affected (64\%) by EUS. 


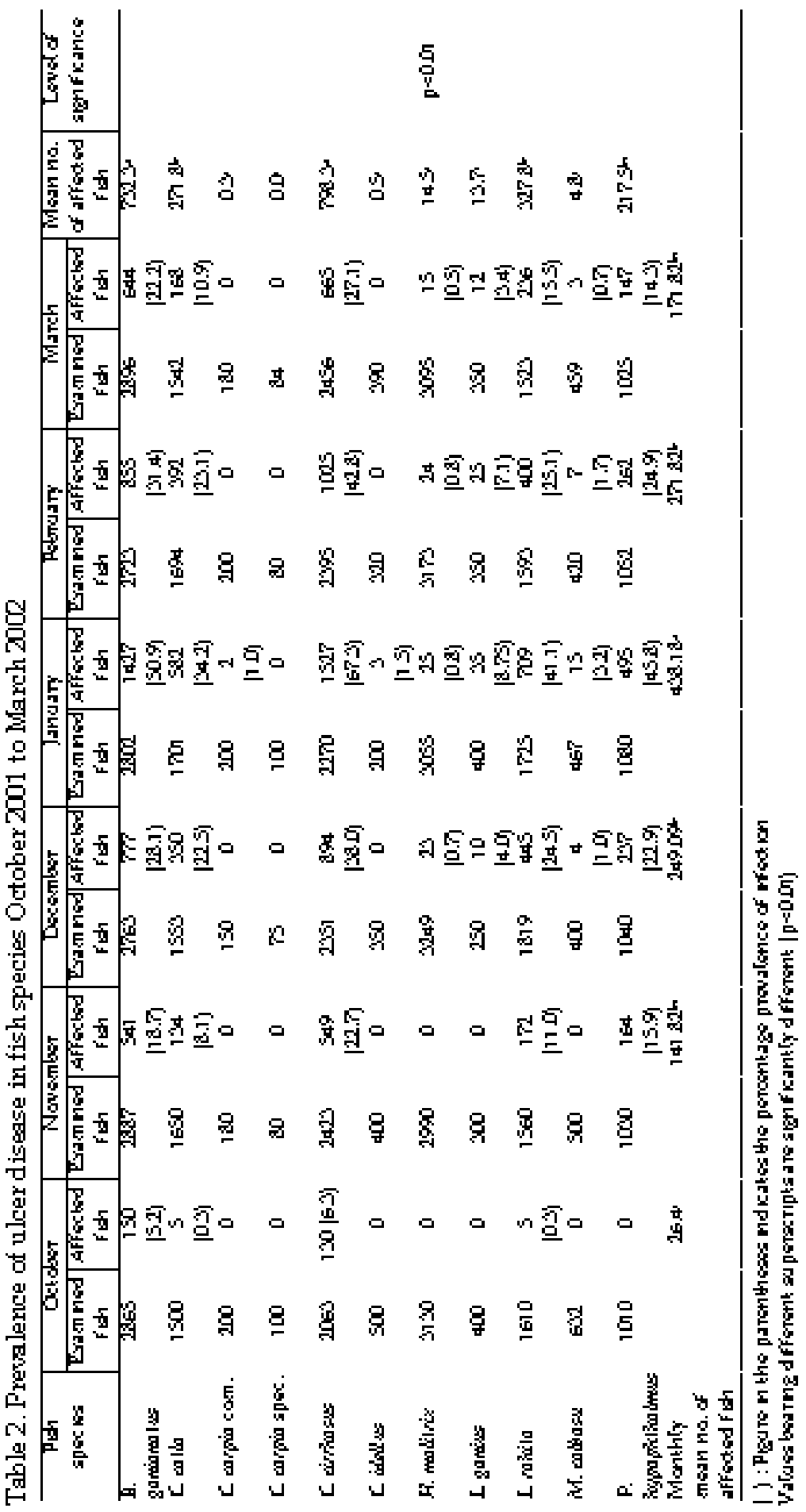




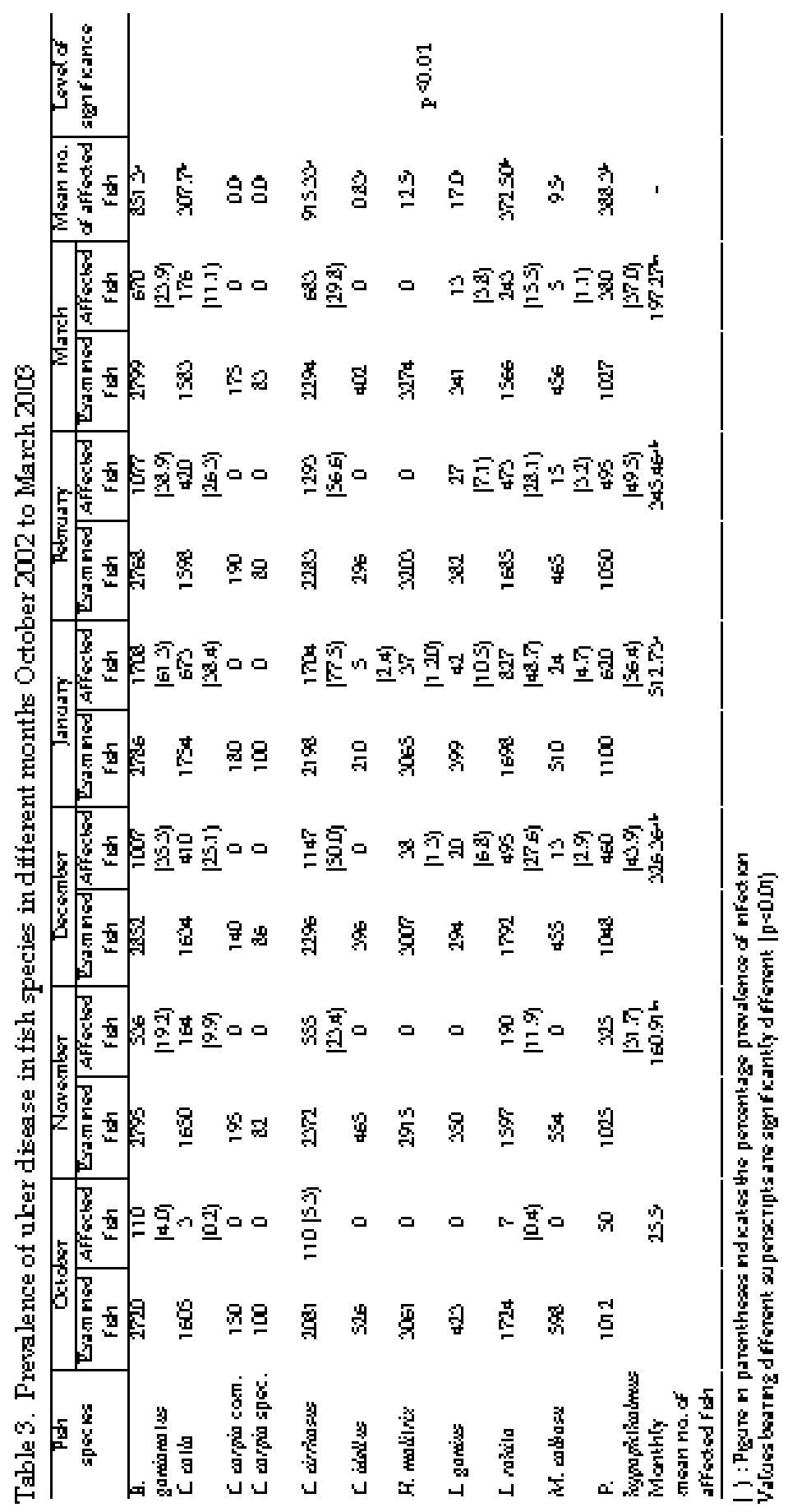


Llobrera and Gacutan (1987) reported that the most severely affected fish in natural outbreaks were some bottom dwellers. The results of the present study correlate with the report of Chowdhury et al. (2003) where C. cirrhosus and B. gonionotus were severely affected. The prevalence of infection was higher in the second year. This may be due to low temperature, which might stress the fish, exposing them to infection.

A total of 167,910 fish belonging to 11 species were examined for ulcer diseases, of which 31,540 (18.8\%) were affected (Table 4). Among the 11 fish species, 6 were histopathologically EUS-positive $(12.0 \%)$ and 4 (6.8\%) were EUS-negative. The EUSpositive species were B. gonionotus, C. catla, C. cirrhosus, L. gonius, L. rohita and M. calbasu, whereas EUS-negative species were C. carpio var. communis, C. idellus, $H$. molitrix and P. hypophthalmus. The highest prevalence of EUS was observed in $C$. cirrhosus $(4.7 \%)$ followed by, B. gonionotus (3.9\%), L. rohita (1.9\%), C. catla (1.4\%), L. gonius $(0.1 \%)$ and M. calbasu (0.0\%). Non-EUS was higher in P. hypophthalmus $(2.2 \%)$ followed by B. gonionotus (1.8\%) and C. cirrhosus (1.4\%). C. cirrhosus was EUS-positive followed by $B$. gonionotus while EUS-negative fish were $C$. carpio var. communis, $C$. idellus and $H$. molitrix. The results obtained correlate with the findings of Sarker (2000) and Khan (2001) who found C. cirrhosus and B. gonionotus were most affected by EUS. Lilley et al. (1992) reported that Indian major carps were much more susceptible to EUS than the Chinese or European carps. Barua (1994) reported that at least 31 different species of fish were affected by EUS and Indian major carps were most commonly affected. Khan (2001) obtained similar results.

Table 4. Prevalence of ulcer disease in fish diagnosed as EUS-positive and EUSnegative

\begin{tabular}{l|c|c|c|c}
\hline \multicolumn{1}{c|}{ Fish species } & $\begin{array}{c}\text { Total examined } \\
\text { fish }\end{array}$ & $\begin{array}{c}\text { Total affected } \\
\text { fish }(\%)\end{array}$ & $\begin{array}{c}\text { EUS-positive } \\
\text { fish }(\%)\end{array}$ & $\begin{array}{c}\text { EUS negative } \\
\text { fish (\%) }\end{array}$ \\
\hline B. gonionotus & 33,656 & $9,502(5.7)$ & $6,500(3.9)$ & $3002(1.8)$ \\
C. catla & 19,464 & $3,477(2.1)$ & $2,375(1.4)$ & $1102(0.7)$ \\
C. carpio comm. & 2,140 & $2(0.0)$ & $0(0)$ & $2(0.0)$ \\
C. carpio spec. & 950 & $0(0)$ & $0(0)$ & $0(0)$ \\
C. cirrhosus & 27,482 & $10,282(6.1)$ & $7,880(4.7)$ & $2,402(1.4)$ \\
C. idellus & 4,455 & $8(0.0)$ & $0(0)$ & $8(0.0)$ \\
H. molitrix & 37,217 & $162(0.1)$ & $0(0)$ & $162(0.1)$ \\
L. gonius & 4,239 & $184(0.1)$ & $126(0.1)$ & $58(0.0)$ \\
L. rohita & 19,892 & $4,202(2.5)$ & $3175(1.9)$ & $1027(0.6)$ \\
M. calbasu & 5,916 & $86(0.1)$ & $60(0.0)$ & $26(0.0)$ \\
P. hypophthalmus & 12,499 & $3,635(2.2)$ & $0(0)$ & $3,635(2.2)$ \\
\hline Total & $1,67,910$ & $31,540(18.8)$ & $20,116(12.0)$ & $11,424(6.8)$ \\
\hline
\end{tabular}

( ) : Figures in parenthesis indicate percentages 


\section{References}

Ahmed M, Rab MA 1995: Factors affecting outbreaks of epizootic ulcerative syndrome in farmed and wild fish in Bangladesh. Journal of Fish Diseases 18 263-271.

Amin MN 2000: Impact of fish diseases on fish culture in Northern region of Bangladesh. Director General, Rural Development Academy, Bogra-5842, Bangladesh pp. 7-17.

Barua G 1994: The status of epizootic ulcerative syndrome of fish of Bangladesh. In: Roberts RJ, Campbell B, MacRae IH, (eds.). ODA Regional seminar on epizootic ulcerative syndrome, Aquatic Animal Health Research Institute, Bangkok pp. 13-20.

Barua G, Banu ANH, Khan MH 1992: An investigation into the prevalence of fish disease in Bangladesh during 1988-89. Bangladesh Journal of Aquaculture 11-13 27-30.

Chowdhury MBR 1998: Involvement of aeromonads and pseudomonads in diseases of farmed fish in Bangladesh. Fish Pathology 33 247-254.

Chowdhury MBR, Muniruzzaman M, Zahura UA, Habib KZA, Khatun MD 2003: Ulcer type of disease in the fishes of small-scale farmer's pond in Bangladesh. Pakistan Journal of Biological Science 6 544-550.

Gomez KA, Gomez AA 1984: Statistical Procedure for Agricultural Research. International Rice Research Institute, John Wiley and Sons, New York, Chichester, Brisbane, Toronto, Singapore, pp. 139-240.

Khan MH 2001: Epidemiological studies on epizootic ulcerative syndrome (EUS) in Bangladesh. $\mathrm{PhD}$ Thesis, Institute of Aquaculture, University of Stirling, Scotland, UK, pp. 250.

Lilley JH, Phillips MJ, Tonguthai K 1992: A review of epizootic ulcerative syndrome (EUS) in Asia. Publication of Aquatic Animal Health Research Institute and Network of Aquaculture Centers in Asia-Pacific, Bangkok, Thailand pp. 19

Llobrera AT, Gacutan RQ 1987: Aeromonas hydrophila associated with ulcerative disease epizootic in Laguna de bay, Philippines. Aquaculture 67 273-278.

Macintosh DJ, Phillips MJ 1986: The contribution of environmental factors to the ulcerative disease condition in South East Asia. In: Roberts RJ (edn). Field and Laboratory Investigation into Ulcerative Fish Diseases in the Asia-Pacific Region FAO, Bangkok. pp. 175-207.

Majumder B, Sarker MGA, Khan MH, Chowdhury MBR 2001: Incidence of ulcer type of disease in wild fishes of Bangladesh. Bangladesh Journal of Fisheries Research 5 163-168.

Post G 1987: Textbook of Fish Health, Revised and Extended edn. TFH Publication, Inc. Neptune City, NJ 07753, USA pp. 288

Rahman MM, Chowdhury MBR, Uddin MN, Pal HK 1998: Prevalence of ulcer disease in some wild fishes in Mymensingh, Bangladesh. Bangladesh Journal of Microbiology 15 9-16.

Rahman MM, Chowdhury MBR 1996: Isolation of bacterial pathogen causing an ulcer disease in farmed carp fishes of Mymensingh. Bangladesh of Journal Fisheries 19 103-110.

Roberts RJ 1989: Fish Pathology, 2nd edn. Bailliere Tindall, London, UK pp. 469.

Roberts RJ, Willoughby LG, Chinabut S 1993: Mycotic aspects of epizootic ulcerative syndrome (EUS) of Asian fishes. Journal of Fish Diseases 16 169-183. 
Sarker MA, Chowdhury MBR, Rahman MM, Kashem MA 1998: Pathogenicity and antibiotic resistance of some Aeromonas hydrophila isolates. Bangladesh Journal Fisheries 21 61-64.

Sarker MGA 2000: Activities of Aeromonas bacteria and Aphanomyces fungus causing EUS in fresh water fishes of Bangladesh. MS Thesis, Department of Aquaculture, Bangladesh Agricultural University, Mymensingh pp. 93

Tonguthai K 1985: A preliminary account of ulcerative fish diseases in Indo-Pacific region (a comprehensive study based on Thai experiences). National Inland Fisheries Institute, Bangkok pp. 39.

Tonguthai K, Chinabut S, Somsiri T, Chanratchakool P, Kanchanakhan S 1999: Diagnostic Procedures for Fin Fish Diseases: Histological Procedure and Bacteriology. Published by Aquatic Animal Health Research Institute, Bangkok, Thailand.

Vishwanath, TSCV, Mohan, Shankar KM 1997: Mycotic granulomatosis and seasonality are the consistent features of epizootic ulcerative syndrome of fresh water and brackish water fishes of Karnataka, India. Asian Fisheries Science 10 155-160. 